https://doi.org/10.15407/frg2019.03.258

УДК 581.19

\title{
ECO-FRIENDLY NANOTECHNOLOGIES: SYNTHESIS OF SILVER NANOPARTICLES USING MEDICINAL PLANTS EXTRACTS
}

\section{O.V. CHIZHIK, V.N. RESHETNIKOV, I.P. KONDRATSKAYA}

\author{
State Scientific Institution «Central Botanical Gardens, National Academy of \\ Sciences of Belarus» \\ 2-v Surganov Street, Minsk BY-220012, Republic of Belarus \\ chizhikolga17@gmail.com, ikondratskaya@mail.ru
}

Green synthesis of metal nanoparticles (NPs) using plant extracts is a nontoxic and ecofriendly method as compared to chemical and physical methods. The production of nanoparticles with plant extract usage has an important advantages. The aim of our research was to establish the conditions for biogenic synthesis of silver nanoparticles using extracts of the medicinal plants and in vitro cultures of medicinal plants. Plant phenolic compounds with strong oxidation-reduction properties can serve as reducing agents of metal ions to NPs. So for the technology of biogenic synthesis of NPs elaboration the most important stage is to choice the plant which will play a role of «biofactory». The medicinal plants and in vitro cultures of medicinal plants have been screened on the biologically active substances (BAS) content, because BAS are the reducing agents for silver nitrate. The phenolic compounds quantitative content screening have revealed that Silybum marianum, Agastache rugosa, Melittis sarmatica and Digitalis purpurea are the best candidates for NPs synthesis. The various factors affecting on the number of synthesized silver nanoparticles have been determined. These factors are: the concentrations of silver nitrate and reducing agents, the time of synthesis, the temperature and $\mathrm{pH}$ of reaction medium. The primary conditions for AgNPs synthesis in Agastache rugosa, Silybum marianum, Melittis sarmatica and Digitalis purpurea extracts have been established. The maximum yield of AgNPs in Agastache rugosa and Digitalis purpurea extracts were observed at $24{ }^{\circ} \mathrm{C}$, for Melittis sarmatica - at $35^{\circ} \mathrm{C}$ and for Silybum marianum extract - at $18^{\circ} \mathrm{C}$. The optimal conditions for AgNPs synthesis $-\mathrm{pH} \mathrm{9,0} \mathrm{and} \mathrm{AgNO}_{3}$ concentration in solution $-1 \times 10^{-2} \mathrm{M}$.

Key words: biologically active substances, callus cultures, in vitro cultures, medicinal plants, nanoparticles.

Currently the field of nanotechnology concerned with the study, synthesis and application of nanoparticles of pure elements and their compounds is actively developing. Nanoparticles (NPs) $(<100 \mathrm{~nm})$ have a high biological activity and are able to pass the membrane barriers of living organisms. Silver nanoparticles (AgNPs) attract attention of researchers because they are widely applied in the fields of electronics [1-3], industry [4-6] and medicine [7,8]. To obtain NPs on an industrial scale, the different phy- 
sical and chemical methods are being used. But these methods are potentially dangerous to the environment. Nowerdays in vitro approaches are in progress [9-11]. Therefore it is necessary to develop the environmentally friendly and efficient methods for NPs production. In recent years new eco-friendly «green» technologies for the biogenic synthesis of NPs are began to develop. Living organisms are the «biofactories» in which NPs are formed by the processes of soluble metal salts reducing [9].

The production of nanoparticles with plant extracts usage has an important advantages. Low cost of cultivation, short production time, the ability to regulate the required volume of products, and safety are make plants an attractive platform for NPs synthesis [8, 9]. During the technology of biogenic synthesis of NPs elaboration the most important stage is to choice the plant which will play a role of «biofactory». Plant phenolic compounds with strong oxidation-reduction properties can serve as agents for reduction of metal ions to NPs $[8,12]$. Therefore the medicinal plants are the best «biofactories» for the NPs production. But to obtain NPs on an industrial scale a large amount of plant material is required. This problem will be solved with the help of biotechnology - in vitro and cell (callus) cultures may supply industry with plant material [13].

Various conditions are affecting NPs synthesis: silver ion concentration, plant extract temperature, $\mathrm{pH}$, time of reaction [8, 12-19]. The $\mathrm{pH}$ modification leads to natural phytoreagent's charges changes in the extract composition. The charges changes affect on phytoreagent's ability to bind and to reduce cations and anions of metals during the nanoparticles synthesis and is reflected on NPs shape, size and yield [12, 20, 21]. Increase of temperature promotes the increase of reaction rate and the efficiency of NPs synthesis $[15,16]$. So it is important to determine the influence of all of this factors on NPs green synthesis.

The aim of our research was to define plants with high content of BAS, and to establish the conditions for the biogenic synthesis of AgNPs with medicinal plants extracts usage.

\section{Methods}

The study was performed in the Department of Biochemistry and Biotechnology of Plants, the Central Botanical Gardens, National Academy of Sciences, Belarus.

The objects of investigations were the medicinal plants and in vitro cultures (Agastache rugosa Kuntze, Digitalis purpurea L., Melittis sarmatica Klok., Silybum marianum (L.) Gaent) from the collection of the Department of biochemistry and biotechnology of plants, the Central Botanical Gardens, National Academy of Sciences, Belarus.

Melittis sarmatica and Digitalis purpurea viable seeds were sterilized with $4 \%$ chlorine solution for 25 minutes. After three successive rinses in sterile distilled water, sterilized seeds were cultured on hormone-free MS medium [22]. When seedlings reached 25-40 days old, the cotyledonous leaves and roots were excised from seedlings and then cultured on MS-basal-medium. Cultivation was carried out at $10 \mathrm{~h}$ light/8 h dark photoperiod and $25 \pm 2{ }^{\circ} \mathrm{C}$. 
Agastache rugosa and Silybum marianum calli were obtained from seeds. Agastache rugosa calli were cultured on solid MS basal medium [22], supplemented with hormones: 0.5 naphthalene acetic acid (NAA) -0.5 $\mathrm{mg} / \mathrm{L}$ and BAP $-0.1 \mathrm{mg} / \mathrm{L}$. Every $15-16$ days calli cultures were subcultured on a fresh medium. The 3-rd passage calli tissues were used for further analyzes.

Silybum marianum calli were subcultured on the MS medium [22] with the hormones addition: BAP $(2 \mathrm{mg} / \mathrm{L})$ and NAA $(1 \mathrm{mg} / \mathrm{L})$. Every $14-17$ days calli cultures were subcultured on fresh medium. The resulting callus cultures were used in further experiments.

The medicinal plants extracts preparation (for BAS content determination) was carried out according to [23] with our modifications. The extraction procedure performed twice. $0.5 \mathrm{~g}$ of plant material were grinded using mortar and pestle followed by addition of 15 мл $70 \%$ (v/v) ethanol. Extract was poured in a flask with a dephlegmator which was put in water bath at $80-90{ }^{\circ} \mathrm{C}$ for $30 \mathrm{~min}$. After that the extract was cooled at room temperature and the precipitate was carefully collected and filtrated through the «rapid» filter. The pellet was washed with $15 \mathrm{ml}$ of $70 \%$ ethanol and the extraction procedure performed again. The obtaining extract volume was $30 \mathrm{ml}$. The extract thus obtained was stored at room temperature in the dark for further experiments.

In order to extracts preparation for NPs synthesis, leaves were washed with Tween 20 and then by double distilled water for three times. $10 \mathrm{~g}$ of leaves were grinded, and boiled with $100 \mathrm{ml}$ of double distilled water at $60{ }^{\circ} \mathrm{C}$ for $10 \mathrm{~min}$. After boiling process the extracts was filtered and supernatant was used for experiments (NPs formation). Polyphenols content were determined by [24]. Measurements were carried out on photocolorimeter SOLAR at wavelength of $765 \mathrm{~nm}$ in a 1-cm-thick cuvette.

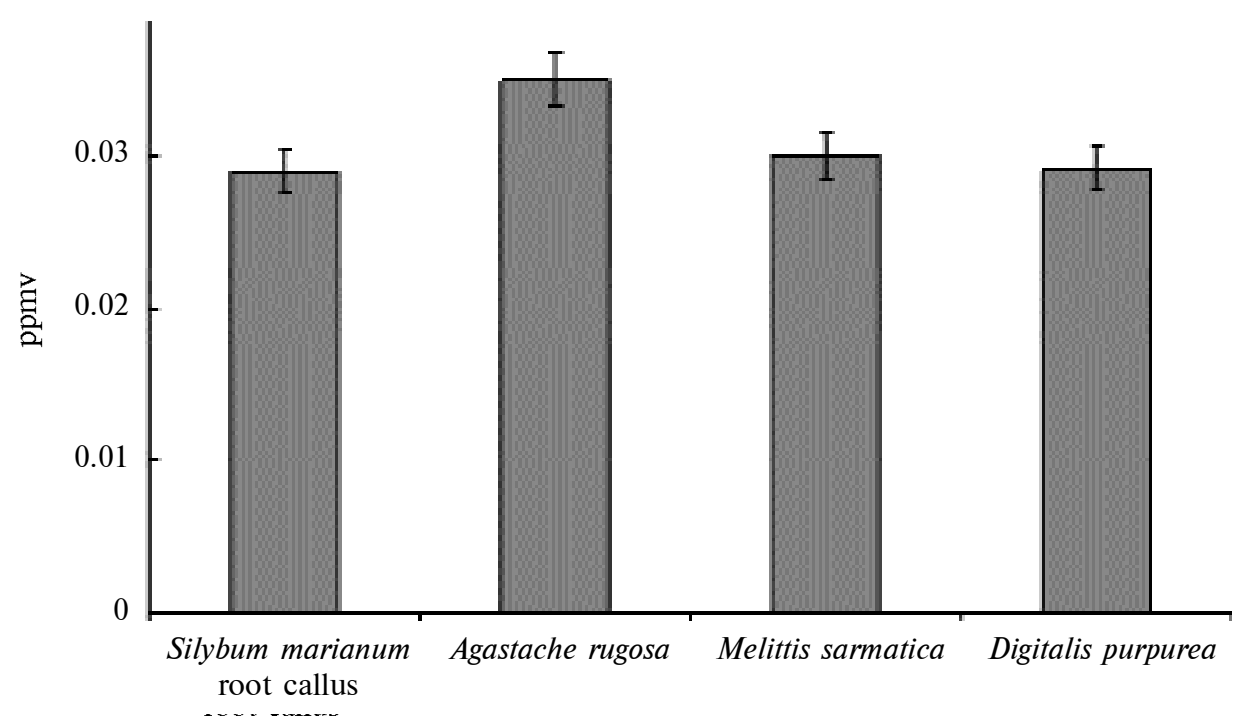

Fig. 1. The total content of phenolic compounds (ppmv) in medicinal plants in vitro culture (Silybum marianum, Agastache rugosa callus cultures, Melittis sarmatica, Digitalis purpurea in vitro shoot cultures) 
TABLE 1. The total content of phenolic compounds in medicinal plants leaves (in-equivalent of gallic acid)

\begin{tabular}{|c|c|c|}
\hline No & Culture & Content, $\mathrm{mg} / \mathrm{g}$ of fresh weight \\
\hline 1 & Agastache rugosa & $18.56 \pm 0.04$ \\
\hline 2 & Digitalis purpurea & $20.78 \pm 0.01$ \\
\hline 3 & Melittis sarmatica & $19.37 \pm 0.02$ \\
\hline 4 & Silybum marianum & $20.17 \pm 0.01$ \\
\hline
\end{tabular}

All analyzes were performed in triplicate, the results were statistically processed using the computer program Statistica 7.0. Distinctions were considered reliable for $p \leq 0,05$.

\section{Results and discussion}

A great number of plant species are capable of NPs synthesizing [25]. The first step of our investigation was to screen the medicinal plants and in vitro cultures of medicinal plants on BAS content in order to define candidates for NPs biogenic synthesis. The phenolic compounds quantitative content screening have revealed that Silybum marianum, Agastache rugosa, Melittis sarmatica and Digitalis purpurea are the best candidates for NPs synthesis.

Fig. 1 shows the total content of phenolic compounds in the extracts of medicinal plants in vitro cultures. Table 1 shows the phenolic compounds content in Silybum marianum, Agastache rugosa, Melittis sarmatica and Digitalis purpurea leaves extracts. This extracts was found to be a good reducing agents for silver nanoparticles synthesis.

To study the optimum factors for AgNPs synthesis, the experiments were carried out at different conditions: $\mathrm{AgNO}_{3}$ concentration in plant extracts $\left(1 \times 10^{-1} \mathrm{M}, 1 \times 10^{-2}, \mathrm{M}, 1 \times 10^{-3} \mathrm{M}\right), \mathrm{pH}(1,3,5,7,9,11)$ and temperature $\left(8,18,24,35\right.$ and $\left.45^{\circ} \mathrm{C}\right)$. The effect of these parameters was monitored by UV-vis spectrophotometer (Agilent 8453). The reaction was carried out in the dark in order to avoid the $\mathrm{AgNO}_{3}$ photoactivation. $\mathrm{AgNO}_{3}$ bioreduction to silver ions was evaluated by the color of the solution changing.

As it is known from literature, when $\mathrm{AgNO}_{3}$ is added to the extracts it results into the colour changing (to brown) due to reduction of silver ions. This color is attributed to surface plasmon resonance. So, the solution's color changing indicates the NPs formation [12, 15, 26-29], and the more brown color of a reaction mixture indicates a higher concentration of nanoparticles [30].

As can being seen from the Fig. 2, the colors of reaction mixtures were from yellowish-green to brown, depending on the extract nature and $\mathrm{AgNO}_{3}$ concentration in solutions. The results are in complete correlation with that of reported by [26, 28]. We have got a maximum AgNPs yield for Agastache rugosa and Melitis sarmatica in vitro cultures in solution with $10^{-2} \mathrm{M} \mathrm{AgNO}_{3}$, and for Silybum marianum and Digitalis purpurea in vitro cultures with $10^{-3} \mathrm{M} \mathrm{AgNO}_{3}$ (Fig. 2). The similar results were obtained by [31]. 


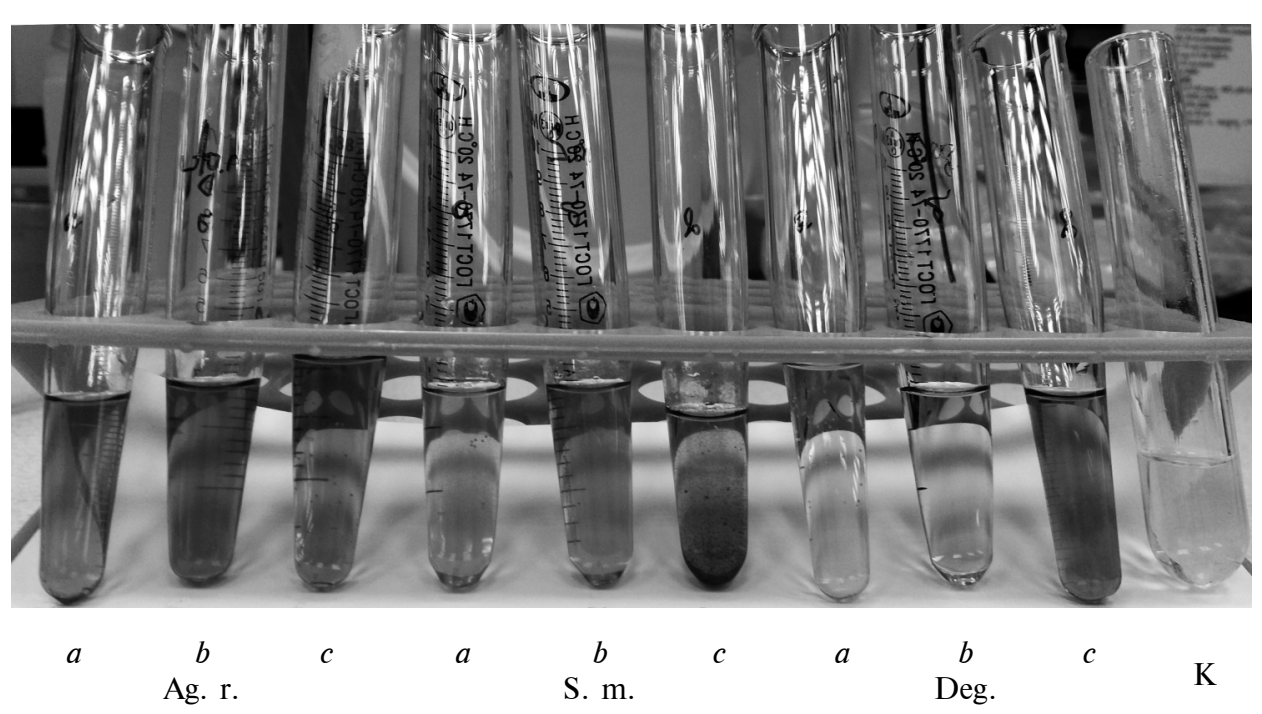

Fig. 2. Reaction mixtures of in vitro cultures of Agastache rugosa (Ag. r.), Silybum marianum (S. m.), Digitalis purpurea (Deg.) extracts at room temperature $\left(18{ }^{\circ} \mathrm{C}\right) \mathrm{AgNO}_{3}$ concentration: $1 \times 10^{-1} \mathrm{M}(a), 1 \times 10^{-2} \mathrm{M}(b), 1 \times 10^{-3} \mathrm{M}(c) ; \mathrm{K}-$ control

TABLE 2. The time required for the maximum amount of silver nanoparticles forming in the extracts of medicinal plants in vitro cultures with $\mathrm{AgNO}_{3}$ solution of $1 \times 10^{-2} \mathrm{M}$ at room temperature $\left(18{ }^{\circ} \mathrm{C}\right)$

\begin{tabular}{l|c}
\hline \multicolumn{1}{c|}{ Culture } & Time, min \\
\hline Silybum marianum (root callus) & 13 \\
Agastache rugosa (leaf callus) & 10 \\
Melittis sarmatica (shoot culture) & 20 \\
Digitalis purpurea (shoot culture) & 16 \\
\hline
\end{tabular}

The next investigated factor was the time required for the completion of reaction. The reduction reaction and formation of NPs starts immediately after the addition of $\mathrm{AgNO}_{3}$ to the plant extract. When the colour of solution becomes constant, no silver salt was left for further reaction. Biogenic synthesis of metal NPs in plant systems is a rather fast process. It was shown that AgNPs were synthesized from an aqueous solution of silver nitrate in a leaf extract of Ocimum sanctum for 8 min [30].

The Table 2 presents data about the time required to form the maximum amount of silver nanoparticles in the extracts of medicinal plants in vitro cultures (the time of extract color development).

In our study the optimum time required for the reaction completion was from 10 to $20 \mathrm{~min}$. The shortest time for color development (for maximum yield of AgNPs formation) was observed for Agastache rugosa (10 $\mathrm{min}$ ) and Silybum marianum (13 $\mathrm{min}$ ) in vitro cultures (Table 2). The data obtained correlated with the higher content of reducing agents in these extracts.

The $\mathrm{pH}$ of plant solution affects on the amount of nanoparticle production and influenced on the rate of the reduction reaction [32]. It was reported that $\mathrm{pH}$ is responsible for the formation of NPs and even the 
extracts coming from different parts of the same plant may have different $\mathrm{pH}$ values which need further optimization for the efficient synthesis of nanoparticles [32, 33]. It seems that $\mathrm{pH}$ affects on the amount of NPs production and stability of them. The reaction mixture turned brown when silver was reduced, and the reaction mixture coloring accelerated when $\mathrm{pH}$ increased.

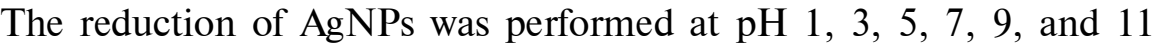
( $\mathrm{pH}$ was adjusted by using $0.1 \mathrm{~N} \mathrm{KOH}$ and $0.1 \mathrm{~N} \mathrm{HCl}$ ). It have been shown that the optimal $\mathrm{pH}$ for AgNPs formation (the maximum absorption of reaction mixtures) was observed at $\mathrm{pH} 9$ (the highest color intensity). Similar results were obtained for Cydonia oblong seed and Cocos nucifera coir extracts [29, 34].

Temperature might be one of the crucial factors affected NPs formation. As known from previous works $[16,35]$ by increasing reaction temperature an increase in absorbance was observed, which can be due to the increase in reduction rate, and production of colloidal silver NPs. However, as experiments have shown, the effect of this factor on the efficiency of NPs synthesis is largely depends on the plant culture. A number of experiments with different temperatures of reaction mixtures $(8,18,24$, 35 and $45^{\circ} \mathrm{C}$ ) have been carried out. As a result it have been found that the maximum yield of AgNPs in Agastache rugosa and Digitalis purpurea extracts were observed at $24{ }^{\circ} \mathrm{C}$, for Melittis sarmatica - at $35{ }^{\circ} \mathrm{C}$ and for Silybum marianum extract - at $18{ }^{\circ} \mathrm{C}$. Our data confirmed that with increase of reaction temperature the production of colloidal silver nanoparticles and reduction rate increased.

Conclusion. The medicinal plants and in vitro cultures of medicinal plants have been screened on the biologically active substances (BAS) content. The data obtained made it possible to reveal 4 in vitro cultures of medicinal plants from the CBG collection which extracts were found to be a good reducing agents for AgNPs synthesis: Agastache rugosa, Silybum marianum, Melittis sarmatica and Digitalis purpurea.

A green synthetic approach by using this extracts for AgNPs preparation have been developed and optimized. Thus, we have established the primary conditions for AgNPs synthesis in Agastache rugosa, Silybum marianum, Melittis sarmatica and Digitalis purpurea extracts. The maximum yield of AgNPs in Agastache rugosa and Digitalis purpurea extracts was observed at $24{ }^{\circ} \mathrm{C}$, for Melittis sarmatica - at $35{ }^{\circ} \mathrm{C}$ and for Silybum marianum extract - at $18{ }^{\circ} \mathrm{C}$. The optimal conditions for AgNPs synthesis $\mathrm{pH} 9.0$ and $\mathrm{AgNO}_{3}$ concentration in solution $-1 \times 10^{-2} \mathrm{M}$.

The authors are grateful to Kovzunova O.V. and Kuzovkova A.A. for their help in the work.

\section{REFERENCES}

1. Colvin, V.L, Schlamp, M.C. \& Alivisatos, A.P. (1994). Light-emitting diodes made from cadmium selenide nanocrystals and a semiconducting polymer. Nature, 370 (6488), pp. 354-357.

2. Wangand, Y. \& Herron, N. (1991). Nanometer-sized semiconductor clusters: materials synthesis, quantum size effects, and photophysical properties. J. Physical Chemis., 95 (2), pp. 525-532. 
3. Wang, Y. (1991). Nonlinear optical properties of nanometer sized semi-conductor clusters. Accounts of Chemical Research, 24, pp. 133-139.

4. Schmid,G. (1992). Large clusters and colloids. Metals in the embryonicstate. Chemical Reviews, 92 (8), pp. 1709-1727.

5. Hoffman, A.J. (1992). Q-sized CdS: synthesis, characterization, and efficiency of photoinitiation of polymerization of several vinylic monomers. J. Physical Chem., 96 (13), pp. 5546-5552.

6. Mansur, H. S. Grieser, F., Marychurch, M.S., Biggs, S., Urquhart, R.S. \& Furlong, D.N. (1995). Photoelectrochemical properties of "Q-state" CdS particles in arachidic acid Langmuir-Blodgett films. J. Chemical Society. Faraday Transactions, 91 (4), pp. 665672.

7. Klaus-Joerger, T., Joerger, R., Olsson, E. \& Granquist, C-G. (2001). Bacteria as workers in the living factory: metal-accumulating bacteria and their potential for materials science. Trends in Biotechnol., 19 (1), pp. 15-20.

8. Makarov, V.V. (2014). "Green" Nanotechnologies: Synthesis of Metal Nanoparticles Using Plants. Acta nature, 6 (1), pp. 35-44.

9. Mittal, A. K., Chisti, Y. \& Banerjee, U.C. (2013). Synthesis of metallic nanoparticles using plant extracts. J. Biotechnol. advances, 31, pp. 346-356. doi:10.1016/ j/.biotechadv. 2013.01.003.

10. Monaliben, Sh., Fawcett, D., Sharma, Sh., Tripathy, S.K. \& Poinern, G.E.S. (2015). Green Synthesis of Metallic Nanoparticles via Biological Entities. Materials J., 8, pp. 72787308. doi:10/3390/ma8115377

11. Malabadi, R., Naik, S., Meti, N.T., Mulgund, G.S., Nataraja, K. \& Kumar, S.V. (2012). Silver nanoparticles synthesized by in vitro derived plants and callus cultures of Clitoria ternatea; Evaluation of antimicrobial activity. Research in Biotechnol., 3 (5), pp. 26-38.

12. Egorova, E.M. (2011). Nanoparticles of metals in solutions: biochemical synthesis, properties and applications. (Extended abstract of Doctor thesis). Moscow [in Russian].

13. Monaliben, Sh., Fawcett, D., Sharma, Sh., Tripathy, S.K. \& Poinern, G.E.S. (2015). Green Synthesis of Metallic Nanoparticles via Biological Entities. Materials J., 8, pp. 7278 7308.

14. Rodriguez-Leon, Er. (2013). Synthesis of silver nanoparticles using reducing agents obtained from natural sources (Rumex hymenosepalus extracts). Nanoscale Res Lett, 8 (1), pp. 318. doi:10.1186/1556-276X-8-318

15. Lin, L. (2010). Nature factory of silver nanowires: Plant-mediated synthesis using broth of Cassia fistula leaf. 162 (2), pp. 852-858. doi: 10.1016/j.cej.2010.06.023

16. Archna, H.R. (2016). Rewew on Green Synthesis of Silver nanoparticle, Characterisation and Optimisation Parameters. International J. Research in Enginee ring and Technol., 5(15), pp. 49-53.

17. Haverkamp, R.G. \& Marshall, A.T. (2009). The mechanism of metal nanoparticle formation in plants: limits on accumulation. J. Nanoparticle Research, 11(6), pp. 14531463. doi:10.1007/s11051-008-9533-6

18. Marchiol, L., Mattiello, A., Poscic, F., Giordano, C. \& Musetti, R. (2014). In vivo synthesis of nanomaterials in plants: location of silver nanoparticles and plant metabolism. Nanoscale Res Lett, 9 (1), pp. 101. doi:10.1186/1556-276X-9-101

19. Mostafa, M.H. (2014). Green synthesis of silver nanoparticles using olive leaf extract and its antibacterial activity. Arabian J. Chemistry, 7(6), pp. 1131-1139.

20. Kumar, R. Choshal, G. \& Goyal, M. (2017). A and Goyal M. Rapid Green Synthesis of Silver Nanoparticles (AgNPs) Using (Prunus persica) Plants extract: Exploring its Antimicrobial and Catalytic Activities. J. Nanomed Nanotechnol, 8 (4), pp. 4-8. doi: 10.4172/2157-7439.1000452

21. Rodriguez-Leyn, E. (2013). Synthesis of silver nanoparticles using reducing agents obtained from natural sources (Rumex hymenosepalus extracts). Nanoscale Res. Lett., $8(1)$, p. 318.

22. Murashige, T \& Skoog, F. (1962). A Revised Medium for Rapid Growth and Bio Assays with Tobacco Tissue Cultures. Physiol. Plantarum, 15 (3), pp. 473-497.

23. Horuzaya, V. (2008). State Pharmacopoeia of the Republic of Belarus. Minsk: Minsk State PTK polygraph named, 2, 381p. [in Russian]. 
24. Riedl, K.M. (2001). Tannin-protein complexes as radical scavengers and radical sinks. J. Agric. And Food Chem., 49 (10), pp. 4917-4923 [in Russian].

25. Baker, S., Rakshith, D., Kavitha, K.S., Santosh, P., Kavitha, H.U., Rao, Y. \& Satish, S. (2013). Plants: Emerging as Nanofactories towards Facile Route in Synthesis of Nanoparticles. Bioimpacts, 3 (3), pp. 111-117.

26. Shankar S., Ahmad, A. \& Sastry, M. (2003). Geranium leaf assisted biosynthesis of silver nanoparticles. Biotechno. Prog., pp. 1627-1631.

27. Vanaja, M., Rajeshkumar, S., Paulkumar, K., Gnanajobitha, G., Malarkodi, C. \& Annadurai, G. (2013). Kinetic study on green synthesis of silver nanoparticles using Coleus aromaticus leaf extract. Advances in Applied Sci. Res., 4 (3), pp. 50-55.

28. Aparajita, V. \& Mohan, S. M. (2016). Controllable synthesis of silver nanoparticles using Neem leaves and their antimicrobial activity. J. Radiation Research and Applied Sci., 9, pp. 109-115. doi:10.1016/j.jrras.2015.11.001

29. Zia, F.N., Iqbal, G.M. \& Mehboo, S. (2016). Green synthesis and characterization of silver nanoparticles using Cydonia oblong seed extract. Appl. Nanosci., 6(7), pp. 10231029.

30. Braroo, K., Sharma, A.K., Thakur, M., Kasu, Y.A., Singh, K. \& Bhori, M. (2014). Colloidal Silver Nanoparticles from Ocimum sanctum: Synthesis, Separation and Their Implications on Pathogenic Microorganisms, Human Keratinocyte Cells, and Allium cepa Root Tips. J. Colloid Sci. and Biotechnol., 3, pp. 1-8.

31. Veerasamy, R., Zi Xin, T., Gunasagaran, S., Foo Wei Xiang, T., Chou Yang, E.F., Jeyakumar, N. \& Dhanaraj, S.A. (2011). Biosynthesis of silver nanoparticles using mangosteen leaf extract and evaluation of their antimicrobial activities. J. Saudi Chem. Society, 15, pp.113-120.

32. Mock, J.J. (2002). Shape effects in plasmon resonance of individual colloidal silver nanoparticles. J. Chem. Physics, 116(15), pp. 6755-6759.

33. Iravani, S. \& Zolfaghari, B. (2013). Green Synthesis of Silver Nanoparticles Using Pinus eldarica Bark Extract. BioMed Res. Int., pp. 1-5. doi: 10.1155/2013/639725

34. Roopan, S.M., Rohit, Madhumitha G., Rahuman, A.A., Kamaraj, C., Bharathi, A. \& Surendra, T.V. (2013). Low-cost and eco-friendly phyto-synthesis of silver nanoparticles using Cocos nucifera coir extract and its larvicidal activity. Ind. Crop Prod., 43, pp. 631635 .

35. Cruza, D., Fale, P.L., Mourato, A., Vaz, P.D., Serralherio, M.L. \& Lino, A.R. (2010). Preparation and physicochemical characterization of Ag nanoparticles biosynthesized by Lippia citriodora (Lemon Verbena). Colloids and Surfaces B: Biointerfaces, 81(1), pp. $67-$ 73

Received 08.02.2019

\title{
ЭКОЛОГИЧЕСКИЕ НАНОТЕХНОЛОГИИ: СИНТЕЗ НАНОЧАСТИЦ СЕРЕБРА С ИСПОЛЬЗОВАНИЕМ ЭКСТРАКТОВ ЛЕКАРСТВЕННЫХ РАСТЕНИЙ
}

\author{
О.В. Чижик, В.Н. Решетников, И.П. Кондрацкая
}

Центральный ботанический сад Национальной академии наук Беларуси, Минск

Зеленый синтез наночастиц металлов с использованием растительных экстрактов является нетоксичным и экологичным методом по сравнению с химическими и физическими методами. Производство наночастиц с использованием растительных экстрактов имеет важные преимущества. Целью нашего исследования было создание условий для биогенного синтеза наночастиц серебра с использованием экстрактов лекарственных растений и культур лекарственных растений in vitro. Растительные фенольные соединения с сильными окислительно-восстановительными свойствами могут служить восстановителями ионов металлов до наночастиц. Поэтому для технологии биогенного синтеза наночастиц наиболее важным этапом является выбор растения, которое будет играть роль «биофабрики». Лекарственные растения и in vitro культуры лекарственных растений были подвергнуты скринингу на содержание биологически активных веществ (БАВ), поскольку БАВ являются восстановителями 
для нитрата серебра. Скрининг количественного содержания фенольных соединений показал, что Silybum marianum, Agastache rugosa, Melittis sarmatica и Digitalis purpurea являются лучшими кандидатами для синтеза наночастиц. Определены различные факторы, влияющие на количество синтезированных наночастиц серебра. Этими факторами являются: концентрации нитрата серебра и восстановителей, время синтеза, температура и $\mathrm{pH}$ реакционной среды. Установлены основные условия синтеза наночастиц серебра в экстрактах Agastache rugosa, Silybum marianum, Melittis sarmatica и Digitalis purpurea. Максимальный выход наночастиц серебра в экстрактах Agastache rugosa и Digitalis purpurea наблюдался при $24{ }^{\circ} \mathrm{C}$, для Melittis sarmatica - при $35^{\circ} \mathrm{C}$, для экстракта Silybum marianum - при $18{ }^{\circ} \mathrm{C}$. Оптимальные условия синтеза наночастиц серебра: $\mathrm{pH} 9,0$, концентрация $\mathrm{AgNO}_{3}$ в растворе $-1 \times 10^{-2} \mathrm{M}$.

Ключевые слова: биологически активные вещества, каллюсные культуры, in vitro, лекарственные растения, наночастицы.

\section{ЕКОЛОГІЧНІ НАНОТЕХНОЛОГІІЇ: СИНТЕЗ НАНОЧАСТИНОК СРІБЛА 3 ВИКОРИСТАННЯМ ЕКСТРАКТІВ ЛІКАРСЬКИХ РОСЛИН}

\section{О.В. Чижик, В.Н. Решетніков, І.П. Кондрацька}

Центральний ботанічний сад Національної академії наук Білорусі, Мінськ

Зелений синтез наночастинок металів із використанням рослинних екстрактів $€$ нетоксичним та екологічним методом порівняно з хімічними і фізичними методами. Виробництво наночастинок із використанням рослинного екстракту має важливі переваги. Метою нашого дослідження було встановлення умов біогенного синтезу наночастинок срібла з використанням екстрактів лікарських рослин та культур in vitro лікарських рослин. Фенольні сполуки рослин із сильними окисно-відновними властивостями можуть слугувати відновниками іонів металів до наночастинок. Отже, для технології розробки біогенного синтезу наночастинок найважливішим етапом $€$ вибір рослини, що відіграватиме роль «біофабрики». Лікарські рослини та культури лікарських рослин in vitro були досліджені на вміст біологічно активних речовин (БАР), оскільки БАР є відновлювальними речовинами для нітрату срібла. Кількісний скринінг вмісту фенольних сполук виявив, що найліпшими кандидатами для синтезу наночастинок є Silybum marianum, Agastache rugosa, Melittis sarmatica i Digitalis purpurea. Визначено різні чинники, що впливають на кількість синтезованих наночастинок срібла. Такими чинниками є: концентрації нітрату срібла і відновлювальних агентів, тривалість синтезу, температура і $\mathrm{pH}$ реакційного середовища. Встановлено головні умови для синтезу наночастинок срібла в екстрактах Agastache rugosa, Silybum marianum, Melittis sarmatica i Digitalis purpurea. Максимальний вихід наночастинок срібла в екстрактах Agastache rugosa i Digitalis purpurea спостерігався за $24{ }^{\circ} \mathrm{C}$, в Melittis sarmatica - за $35^{\circ} \mathrm{C}$, в екстракті Silybum marianum - за $18{ }^{\circ} \mathrm{C}$. Оптимальні умови синтезу наночастинок срібла: $\mathrm{pH} 9,0$, концентрація $\mathrm{AgNO}_{3}$ в розчині $-1 \times 10^{-2} \mathrm{M}$.

Ключові слова: біологічно активні речовини, калюсні культури, in vitro, лікарські рослини, наночастинки. 